\title{
The development of regional differentiation of office construction in the Czech Republic: 1990-2010
}

\author{
Pavel DOMALEWSKI ${ }^{\mathrm{a}}$, Jan BAXA ${ }^{\mathrm{a}}$
}

\begin{abstract}
The factors that were crucial for the construction of administrative buildings in the regional capitals of the Czech Republic are subject to examination in this article. One primary question is whether the development of office construction reflects the qualitative importance of the cities, or whether there are some other regularities in the spatial distribution of construction. To identify the key factors, controlled interviews with experts professionally involved in the construction of administrative buildings were carried out, and these data were then extended as part of a large-scale questionnaire survey with other experts on the issue. The results have confirmed the dominant position of the capital city of Prague in terms of its qualitative importance, as the remaining regional capitals have less than one-tenth of the volume of modern office building areas. The greatest differences in the construction of administrative buildings have been noted in Brno and Ostrava, despite the fact that they exhibit similar characteristics when considered in the light of respondent-determined factors.
\end{abstract}

Keywords: administrative buildings, regional differentiation, localisation, office construction, Czech Republic

\section{Introduction}

There have been a number of changes in the Czech economy after 1989 due to transformation processes (Hampl et al., 2001; Hampl, 2005; Hampl, 2010; Bičík and Jančák, 2006; Stanilov, 2007). As one example, the country witnessed a considerable inflow of foreign firms from the progressive tertiary sector, as well as the establishment of a number of domestic companies in this economic segment. "Progressive", in this context, refers to the niche in the tertiary sector which has the highest added value, at the notional peak of the pyramid of services: e.g. banking, insurance services, etc. (for further elaboration, see Blažek, 2001). These entities started to apply new approaches, not only to the implementation of their business activities but also to the operation of their businesses, aiming to increase work efficiency and improve employee work environment. Therefore, they started to use modern office premises which shape a firm's prestige and provide employees with a comfortable environment to deliver required performance. As a result, office demand was one of the impulses for the development of construction of administrative buildings in Czech towns since the first years of economic transformation (Sýkora, 1999; Sýkora, 2007; Stanilov, 2007). The construction of office buildings, however, is not based solely on demand. Rather, it is a complex process of interaction of many inter-related factors in time and space, and one that has significant regional impacts (Fisher and Collins, 1999; Fisher, 2005; Rebelo, 2010).

The construction of office buildings in the Czech Republic has reached the point of substantial regional differences over the last twenty years, in common with most socio-economic phenomena. Aside from overall macroeconomic and political conditions, the essence of the regional differences needs to be sought in diverse, mostly qualitative, characteristics at meso-regional, micro-regional and perhaps also local levels. The development of construction of office buildings has also significantly affected the physical, functional and social structure of cities (Stanilov, 2007; Sýkora, 2007). This important theme of regional differentiation, however, has not been sufficiently addressed in existing research. The current situation with respect to the structure of demand for office spaces for various branches of the tertiary sector in the Czech Republic is illustrated in Figure 1.

This article aims to describe and explain the spatial diffusion of the construction of international top-quality standard rental administrative buildings (hereinafter the "office buildings") in Czech regional capitals over the past twenty years. We ask two questions in connection with this objective. First, we would like to find out whether the increasing construction reflects the qualitative importance of designated cities, or whether there are some irregularities in the expected pattern of the spatial distribution of modern offices. Second, we would like to find out what factors influenced the construction of administrative buildings in Czech regional capitals, as well as their spatial distribution.

\section{Approaches to the study of construction of office buildings}

Research on the construction of office buildings can be primarily understood as part of real estate research in general: for example, Bertz (2002), Adair et al. (1999), Carn, Rabianski, Racster and Seldin (1988). Some research, however, focuses on the retail segment (Des Rosiers and Thérault, 2014), while other works deal with industrial real estate properties, whether in the form of brownfields (Garb and Jackson, 2010) or in the form of greenfields and logistics parks. Last, but not least, a considerable amount of research has focused on non-commercial real estate in the Czech Republic, especially the residential market (Lux and Sunega, 2011; Nedomová [ed.], 1999).

In our review of the literature, we put particular emphasis on understanding the wider context of the construction of office buildings. Therefore, research dealing with the causes

\footnotetext{
${ }^{a}$ Department of Social Geography and Regional Development, Charles University in Prague, Faculty of Science, Prague, Czech Republic; (corresponding author: J. Baxa, e-mail: jan.baxa@yahoo.com)
} 


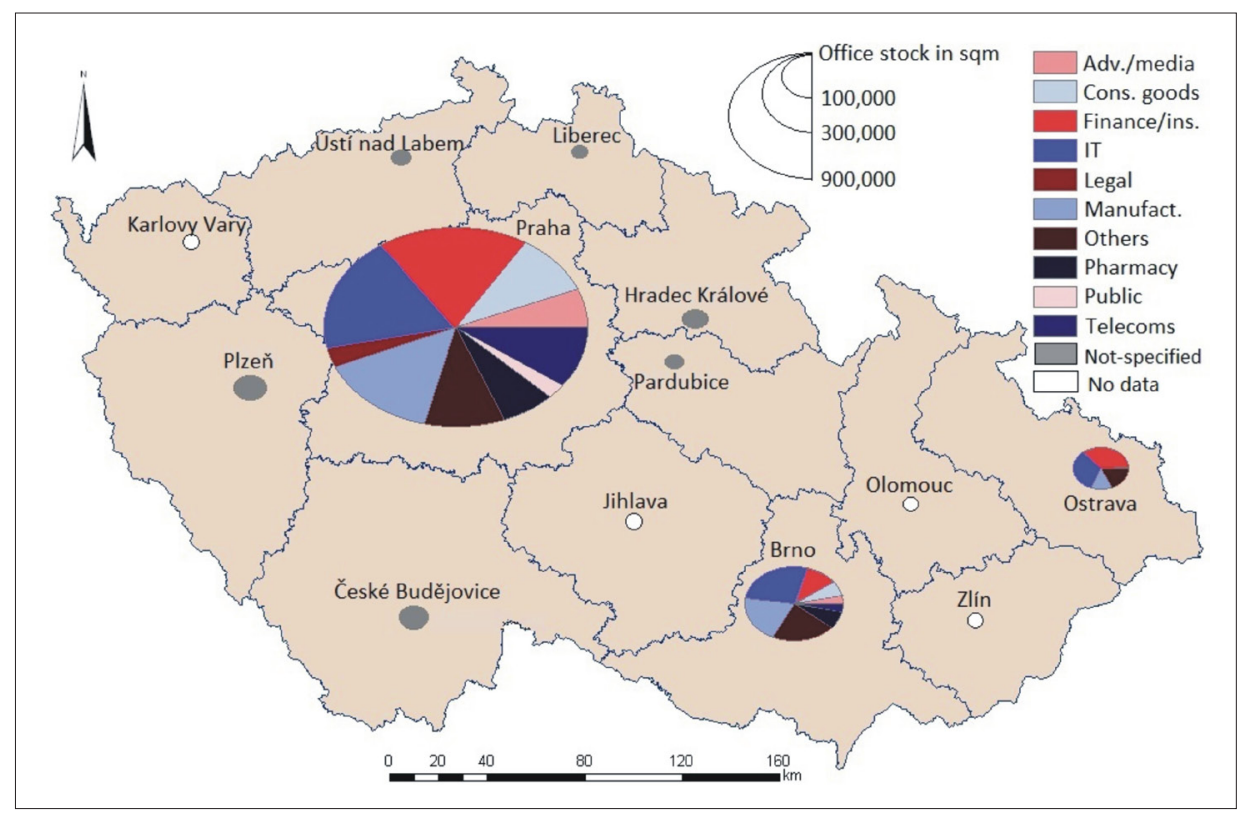

Fig. 1: Office stock in the Czech Republic and structure of the demand for office spaces

and consequences of concentration processes in the context of wider socio-geographical and economic changes in society provided us with useful findings (e.g. Sassen, 1995). The current situation in the Czech Republic can be characterized by the "increasing importance of major cities acting as centres thanks to the concentration of the control functions" (Hampl, 2005, p. 21; original Czech text translated to English by the authors). Following this idea, one can assume that the most important (progressive) economic activities, information and power are concentrated in areas smaller than those concentrating the population and other (non-progressive) activities. We assume, as well, that these tendencies create optimum conditions for the development of a physical, social and functional city environment, which is reflected in the increasing construction of modern office buildings.

Many of the research contributions address the impacts of socio-geographical and economic changes on the market for administrative premises. Sýkora (2007) explains that governmental reforms (privatization, liberalization of prices and deregulation of rents), the increasing demand for modern office premises by newly-emerging Czech firms and an inflow of foreign companies and investors, represented an important stimulus for the development of the real estate market. This author assumes that this subsequently led to the commercialization, revitalization and regeneration of urban zones. In broader contributions on post-socialist metropolises (Stanilov, 2007, and others), an emphasis is placed on the growing interest of foreign investors in Central and East European markets, who saw advantageous and returnable investments behind the growing demand for commercial real estate properties. General issues related to the development of commercial real estate properties are dealt with by Gotham (2006) and Parsa, McGreal, Keivani (2000), for example, who stress the role of State policy and the effect of the global economy on the construction of administrative buildings. Rebelo (2010) and Aarhus (2000) highlight the influence of community policy and other local institutions. Wood (2004), Sýkora (2007), D’Arcy and Koegh (1997), McGough and Tsolacos (1997) consider economic factors to be the most important impulses for the construction of office buildings. Factors viewed as the most fundamental include, in particular, GNP structure and growth rate (D'Arcy and
Koegh, 1997), level of industrial production, employment, rent prices, investment environment maturity (McGough and Tsolacos, 1997), or the development of new financial mechanisms (Wood, 2004).

Using the specific example of the Prague district of Smíchov, Temelová (2007) has described the forces and mechanisms which led to the substantial deindustrialization of the area and its subsequent commercialization and the construction of prestigious and representative projects (flagship developments). As well, Ilík and Ouředníček (2007) focused on the metamorphosis of Prague's Karlín district in the context of transformation processes, and mention also the importance of the development of office buildings during this process (Fig. 2 - see cover p. 4 ).

Much less attention has clearly been paid to the classification of localization factors of office construction in Czech language literature. For the purposes of this article and, in particular, to offer our own categorization of localization factors, we built on the methodological bases published in work by Fisher and Collins (1999) and Fisher (2005). Fisher and Collins (1999) identified four dimensions which determine the construction of office buildings by mutual interaction. They are (i) structure, (ii) actors, (iii) events, and (iv) location. They consider 'structure' to be the most important dimension and understand it as a set of contextual forces (economic forces, technologies, external environment, social forces, political and government forces) determining the behaviours of participants, the sequence of events, and use of individual lands. Fisher (2005) elaborates on this model of localization factors and presents a network model. It is based on seven essential elements: long-term trends, economy, the situation in real estate markets, participants, governmental activity, land localities and the sequence of events. These elements are further classified into sub-elements that are inter-related in the form of functional relations. It should be mentioned as well that the classification of localization factors is dealt with in other works (e.g. Wilkinson and Reed, 2008; Birell and Gao, 1997; Bertz, 2002). This research, however, usually concerns general development models with very limited applicability to the conditions of Czech towns. 
In summary, evaluation of the construction of office buildings has so far been made against the background of a broad spectrum of socio-economic factors. We assume, based on knowledge available in the research literature, that the development of office construction in Czech towns is dependent on the improving economic and legislative requirements of the State, on the one hand, and, predominantly, on the development of the economic and social characteristics of individual regions and their centres, on the other hand.

\section{Research methodology}

First, we analysed office construction data. The reporting twenty-year period was divided into several phases, depending on the extent of construction in individual regional capitals in the Czech Republic. The phasing principle relied on assigning the towns to size categories and, subsequently, on defining the year in which the individual towns or size categories had entered the administrative market (i.e. the first office projects had been finished and the development had continued in the following years). An explanation of the individual phases was based on an analysis of key localization factors. These localization factors had been established on the basis of controlled interviews with real estate experts, and assigned a level of importance by a broader range of real estate professionals.

\subsection{Data base to describe office development}

To provide a description of the construction of new administrative international top-quality standard buildings, it was necessary to use appropriate and accurate data. For this purpose, we used data from Cushman \& Wakefield Ltd., keeping records of the construction of "A" standard buildings (see Table 1) in the Czech Republic from 1990. The choice of the data source relied on the fact that renowned international real estate agencies (such as Jones Lang LaSalle, CBRE, Colliers, Knight Frank, DTZ, and Cushman \& Wakefield) had carefully processed databases of this (commercially attractive) building segment as opposed to various public sources.

It must be noted, however, that there are other categories of lower-standard office areas, but it is not realistic to collect the data in terms of their completeness. The problem of data credibility and completeness is mentioned also by Sýkora (2007), who points out that data on administrative areas published by real estate agencies do not include, for example, non-refurbished offices built before 1990, refurbished buildings not offered for letting in the real estate market, buildings built by companies to serve their own purposes, and a huge amount of small and 'not-toogood' offices. Office buildings under construction that were expected to be finished during 2011 or 2012 were not taken into account in describing this construction.

\subsection{Procedure in determining key localization factors}

The starting point for determining key localization factors was a network model of elements and sub-elements affecting commercial development according to Fischer (2005): see Table 2. One disadvantage of this model for our research is, in particular, its excessive generality and universality, as it can be applied to the development of not only office buildings but also of retail areas and other commercial areas. Another disadvantage of the Fisher model can be seen in not

I. Good transport accessibility (public transport, connection to the main highways, railway corridors and the airport)

II. Sufficient public amenities within the location

III. Top-quality technical and user standard of the office building (modern cable management; a building must feature one of the following: raised floors / suspended ceilings with power poles or cable trays / compartment trunking / provision for under-floor cabling, a modern air handling system ( 2 or 4 pipe air conditioning), adequate provision of secure dedicated car parking (a building location is considered when assessing this criteria), 24-hour access and security, a high quality standard finish, modern lift(s), good accessibility by public transport (walking distance to metro station max. 15 minutes), clear ceiling height of at least $2.65 \mathrm{~m}$, prestige / quality reception area, flexible design partitioning, sufficient lighting, sprinkler system / fire security, amenities in the building / immediate vicinity, well-managed property).

Tab. 1: Definition of administrative international quality standard buildings (standard "A" - this top quality technical standard building must fulfil criteria I., II., and at least $70 \%$ of indicators of criterion III.) Source: adjusted according to Prague research forum, 2014

\begin{tabular}{|l|l|}
\hline \multicolumn{1}{|c|}{ Elements } & \multicolumn{1}{c|}{ Sub-elements } \\
\hline Long-term Trends & Population, society, technology, transport, politics, environment \\
\hline Economy & Business sectors, finance and investment markets, economic cycle, regional economies \\
\hline Property Markets & $\begin{array}{l}\text { Property letting markets, property finance markets, property investment markets, construction } \\
\text { markets, land markets, housing markets }\end{array}$ \\
\hline Actors & $\begin{array}{l}\text { Banks, occupier, investor, contractor, property consultant, design consultant, lawyer, landowner, utility, } \\
\text { developer }\end{array}$ \\
\hline Government & Legislation, economic policy, policy, agency, local government, local planning authority \\
\hline Events & $\begin{array}{l}\text { Inception, market research, financing, feasibility, site investigation, design, town planning, site purchase, } \\
\text { procurement, construction, promotion, letting, sale, completion }\end{array}$ \\
\hline Site & Location, physical characteristics, ownership, construction, new property \\
\hline
\end{tabular}

Tab. 2: Property development web model. Source: Fisher, 2005 
distinguishing between the weights of individual indicators (for example, the roles of a building design and the real estate market situation, represent completely different important categories in the development process). Nevertheless, the model is beneficial with respect to its complexity - i.e. it defines all potential spheres of influence on commercial development. Therefore, the model was used as a basis for controlled interviews with professionals from the area of construction of administrative buildings.

These controlled interviews aimed at identifying a set of factors influencing the construction of office buildings in Czech regional capitals. The interviews were made with Mrs. Radka Novak (Head of Office Agency, Cushman \& Wakefield, and formerly the Letting Manager, SKANSKA), Mr. Alexander Rafajlovič (Head of Research, Cushman \& Wakefield), Mrs. Alexandra Tomášková (Letting and Development Manager, SKANSKA), Mr. Pavel Skřivánek (Letting director, CPI), and Mr. Přemysl Chaloupka (Managing Director, Knight Frank), from 14 July 2011 to 30 July 2011. This is a selection of reputable experts with many years of experience in the construction of office buildings and commercial real estate. The interviews took place separately. Discussions with the interviewees first concentrated on the validity of the elements and sub-elements as outlined in the Fisher model, for the conditions of the Czech Republic. The experts were asked to identify sub-elements they considered to be important for office construction. Then they were asked about what other factors beyond the Fisher model played a role in the development of office buildings. The result of the controlled interviews was a list of 32 localization factors.

The next step was a questionnaire survey aimed at identifying a narrower range of key localization factors out of the initial set of 32 . The questionnaire survey was conducted in the form of e-mailed questionnaires from August 1, 2011 to September 30, 2011.

We approached a total of 102 respondents, of which 54 answered. In the survey we asked developers, employees of international real estate agencies and other experts on office construction, to assess the individual factors and rate them by their importance for development in regional capitals in the Czech Republic on a scale 1 to 10 (where $1=$ lowimportance factor for the construction of office buildings, $\ldots$, and $10=$ high-importance factor for the construction of office buildings). The respondents had an option to give and rate other factors which they considered being significant and which were not listed among the 32 factors, and to comment on the individual factors. An average point score (alphasection/trimmed mean) was subsequently calculated for the individual factors based on the questionnaires completed.

The questionnaire survey results, however, did not establish that there was a narrower range of more significant factors. The point scores of the individual factors indicated relatively small differences (Tab. 3), as evidenced by the minor difference between the highestimportance factor ("Demand" = 8.84) and the lowestimportance factor ("Levels of Unemployment Rate of University Graduates" = 4.82). For this reason, we had to abandon the idea of identifying a narrow range of factors with significantly higher importance levels. As a result, we decided to evaluate all relevant factors with a score higher than 5.00. In addition to the low-score factors, we left aside also factors which, in our opinion, were general, i.e. of the same function at the macro-regional level of the development system. There were 26 factors left from the original set after these eliminations.
There were minor differences between answers from men and women (less than 0.2 points), but a significant difference was found between groups of experts in evaluation of the importance of "Government investment incentives" (developers marked them 3 points less than advisors, and 1.5 less than other experts), and evaluation of "The important real estate agencies", as advisors see their business as much more important than the other experts.

These factors were classified into six groups (aggregates) based on their similarity from the point of view of their impacts on the construction of office buildings. For further comparison of the aggregates in terms of their importance, we defined their size (= sum of the weights of the relevant factors) and weight (the size of an aggregate was standardized to the sum of all 26 factors as equivalent to ten). The resulting values reveal interesting findings. According to the developers and real estate professionals, the most important role for the construction of office buildings in regional capitals is played by the situation in real estate markets (2.99). On the other hand, environmental quality is the least important (0.7). The remaining aggregates range between 1.29 and 1.79 and are approximately of similar significance. The results can be interpreted logically as follows: developers make their decisions about the construction of administrative buildings mainly on the basis of the real estate market situation and its expected future development. They consider the other aggregate factors to be equally important, and reflect on them in a complex decisionmaking process. Environmental quality is paid the least importance, probably because they think it to be sufficient enough in all regional capitals in the Czech Republic and thereby less limiting for office construction.

The classification of the factors and their subsequent weighted aggregation are used in the next section to explain the development and regional differentiation of the construction of office buildings. Regarding the extensive need for data which, in our case, cannot be obtained in their completeness, we are not able to make a sophisticated quantitative analysis. Therefore, we seek to explain construction in the individual towns using a description of the development of the individual aggregates, factors or their proper substituents if monitored by the Czech Statistical Office, in particular. The incompleteness of the source data for the reporting regional capitals is dealt with by using some of the data for the entire region, i.e. roughly the catchment areas of the regional capitals. More specifically, we used data for the following factors / substituents: at the level of the capitals - number of citizens; at the level of the regions general rate of unemployment, average wages, percentage of employees in the progressive tertiary sector (of ratios of those employed in financial services and insurance, real estate, information and communication), number of university students, access of the regional capitals to the motorway and railway network, and presence of an international airport. Save for traffic signs, Prague was evaluated independently of the Středočeský Region because it is perceived by interviewed experts as a separate region. Also, values of the analysed indicators for this Region are significantly lower in comparison to Prague, and do not enhance the importance of the Czech Capital on the commercial real estate market.

\subsection{Construction phasing principle}

The regional capitals were divided into three size categories (Tab. 4): towns with more than 500 thousand inhabitants (Prague), towns with more than 250 thousand 
and less than 499 thousand inhabitants (Brno, Ostrava), and towns with up to 249 thousand inhabitants (remaining regional capitals).

From the available construction data, we determined in which years the construction of modern office buildings was carried out. We emphasize, in connection with this principle of categorization of the towns, that we are aware of the fact that this hierarchical division of the towns does not replicate other hierarchical patterns, such as the rank-size rule established by the number of inhabitants (e.g. Hampl, 2005), or the quality of the business environment (Viturka, 2010). The individual phases of construction are analysed in the following section. The text is structured by these indicated hierarchical groups of towns or their current involvement in the real estate market for office properties.

\section{Development of construction of administrative buildings in the Czech Republic, 1990-2010}

Following the evaluation of the data on office construction in Czech towns and cities, we identified three phases (see Fig. 2), differing not only in construction intensity but also in the spatial distribution of finished modern office buildings.

\begin{tabular}{|c|c|c|c|c|}
\hline Aggregate & Factor & Weight of factor & Size of aggregate & $\begin{array}{l}\text { Weight of } \\
\text { aggregate* }\end{array}$ \\
\hline \multirow{3}{*}{ Accessibility } & The international airport & 6.74 & \multirow[b]{3}{*}{23.08} & \\
\hline & Transport accessibility & 8.14 & & \\
\hline & The city transport infrastructure & 8.20 & & 1.29 \\
\hline \multirow{4}{*}{ Local activities } & City promotion & 5.66 & \multirow[b]{4}{*}{26.42} & \\
\hline & Local actors & 6.22 & & \\
\hline & The image of the city & 7.10 & & \\
\hline & Local self-government support & 7.44 & & 1.48 \\
\hline \multirow{5}{*}{ Economy } & Unemployment rate of university graduates** & 5.04 & \multirow[b]{5}{*}{31.20} & \\
\hline & The ratio of employed in progressive services & 5.98 & & \\
\hline & Levels of unemployment rate & 6.10 & & \\
\hline & Low labour costs & 6.62 & & \\
\hline & Acquisition of the development site & 7.46 & & 1.75 \\
\hline \multirow{2}{*}{ Environment } & Environment & 6.18 & \multirow[b]{2}{*}{12.52} & \\
\hline & Social environment & 6.34 & & 0.70 \\
\hline \multirow{7}{*}{$\begin{array}{l}\text { Real estate } \\
\text { market }\end{array}$} & The important real estate agencies - letting & 5.52 & \multirow[b]{7}{*}{53.46} & \\
\hline & A well-established office market & 7.44 & & \\
\hline & Levels of office rent & 7.68 & & \\
\hline & Competition & 7.84 & & \\
\hline & Levels of office vacancy & 7.90 & & \\
\hline & The activity of the investment market & 8.24 & & \\
\hline & Demand & 8.84 & & 2.99 \\
\hline \multirow{5}{*}{$\begin{array}{l}\text { Social and human } \\
\text { capital }\end{array}$} & Science-technology parks & 5.08 & \multirow[b]{5}{*}{31.98} & \\
\hline & Number of university students & 6.06 & & \\
\hline & The ratio of university graduated & 6.30 & & \\
\hline & Public amenities & 7.14 & & \\
\hline & Population size & 7.40 & & 1.79 \\
\hline \multirow{7}{*}{$\begin{array}{l}\text { Factors } \\
\text { not further } \\
\text { analysed }\end{array}$} & Factor & Weight & \multicolumn{2}{|c|}{ Reason of elimination } \\
\hline & Unemployment rate of university graduates ${ }^{* * *}$ & 4.82 & \multicolumn{2}{|c|}{ Weight $<5.00$} \\
\hline & The proximity to the borders & 4.90 & \multicolumn{2}{|c|}{ Weight $<5.00$} \\
\hline & The accessibility of debt financing & 8.18 & \multicolumn{2}{|c|}{ general effect } \\
\hline & Knowledge of foreign languages & 6.32 & \multicolumn{2}{|c|}{ general effect } \\
\hline & Government investment incentives & 5.70 & \multicolumn{2}{|c|}{ general effect } \\
\hline & Opportunities for expats & 4.88 & \multicolumn{2}{|c|}{ Weight $<5.00$} \\
\hline
\end{tabular}

Tab. 3: Questionnaire survey results and subsequent data. Notes: *on the condition that the sum of all 26 factors is equivalent to ten; **in terms of high levels as a possible source of labour; ***in terms of low levels as an indicator of economic conditions of a city and its catchment area.

Source: Expert survey 2011, calculations by the authors 
It must be noted, in connection with the definition of the individual phases, that it is not possible to exactly determine the 'break-point' years between the periods because the consecutive phases overlap to a certain extent. The planning and development of a single administrative building may take from two to three years. Thus, the status of construction in 2004 reflects the situation in the real estate market as it was in approximately 2002.

As regards construction intensity, we can see in Figure 3 that the market for administrative premises in Czech underwent, during these twenty years of development, a creation or low-intensity period (Phase I), a development or growing-intensity period (Phase II-III), and a stagnation or decreasing-intensity period (Phase III), where the stagnation period is visible in the persistent, greatly limited construction of office buildings. From our point of view, however, it is important to divide this period by the involvement of the individual towns or size categories of the towns we have defined, in the market for office buildings.

\section{A) 1990-1996 (creation of the administrative market)}

There were not any fundamental differences among Czech regions and towns shortly after 1990 due to the previous long-term and State-controlled levelling of regional differences (Havlíček, Chromý, Jančák, Marada, 2005). There had been changes, primarily in the socio-economic area, including the real estate market, shortly after the transformation of the political situation and simultaneously with the implementation of the first economic reforms.

Until 1996 offices were built in the Capital City of Prague only. The first modern building there was finished in 1993, followed by several completed buildings in subsequent years. The process was explained by Stanilov (2007), Sýkora, Kamenický, Hauptmann (2000), and Sýkora (1999, 2007), who relate the origins of the Czech real estate market especially to post-revolutionary developments in Prague, where there was a dynamic growth of private firms, both Czech and foreign companies demanding modern offices, as a result of the transformation and transformation-conditioned processes (e.g. liberalization of trade and prices, gradual deregulation of rents, privatization). Prague was perceived by those companies mainly as the chance to expand their activities and as a "gate to Central and Eastern Europe" (Sýkora, 1999; Sýkora, 2007; Drbohlav and Čermák, 1998). Sýkora's observations on 'demand' are confirmed by

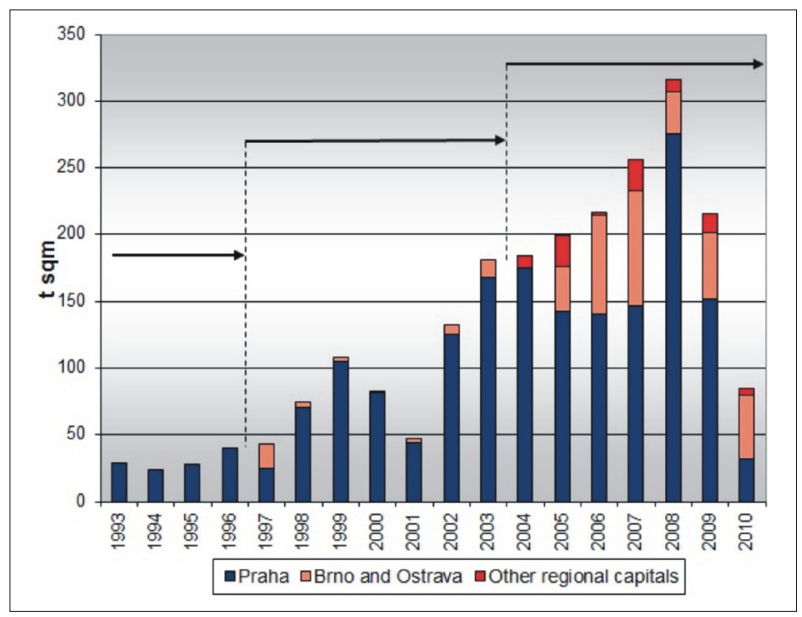

Fig. 3: Office construction in the regional capitals of the Czech Republic: 1990-2010. Source: Cushman \& Wakefield, 2011

\begin{tabular}{|c|c|c|c|c|c|c|c|}
\hline 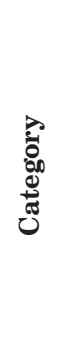 & 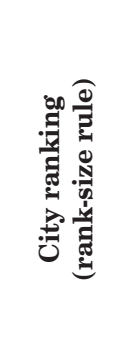 & 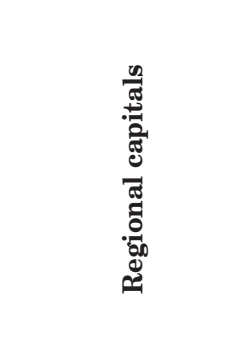 & 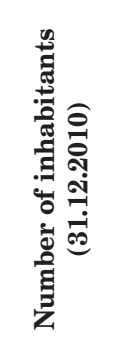 & 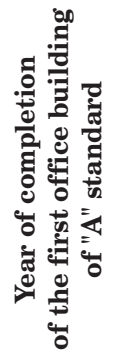 & 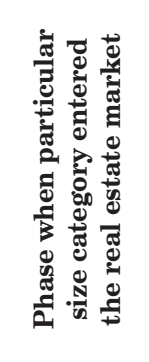 & 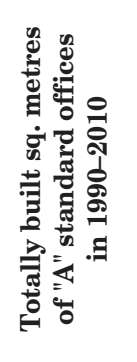 & 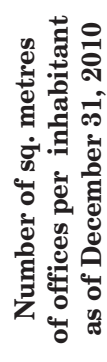 \\
\hline I & 1. & Praha & $1,257,158$ & 1993 & $1990-1996$ & $1,804,448$ & 1.44 \\
\hline II & $\begin{array}{l}2 .-4 . \\
2 .-4 .\end{array}$ & $\begin{array}{l}\text { Brno } \\
\text { Ostrava }\end{array}$ & $\begin{array}{l}371,371 \\
303,609\end{array}$ & $\begin{array}{l}1997 \\
2003\end{array}$ & $1997-2003$ & $\begin{array}{l}270,924 \\
101,200\end{array}$ & $\begin{array}{l}0.73 \\
0.33\end{array}$ \\
\hline III & $\begin{array}{l}2 .-4 . \\
5 .-12 . \\
5 .-12 . \\
5 .-12 . \\
5 .-12 . \\
5 .-12 . \\
5 .-12 . \\
5 .-12 . \\
13 .-34 . \\
13 .-34 .\end{array}$ & $\begin{array}{l}\text { Plzeň } \\
\text { Liberec } \\
\text { Olomouc } \\
\text { Ústí nad Labem } \\
\text { České Budějovice } \\
\text { Hradec Králové } \\
\text { Pardubice } \\
\text { Zlín } \\
\text { Jihlava } \\
\text { Karlovy Vary }\end{array}$ & $\begin{array}{r}168,808 \\
101,865 \\
100,233 \\
95,464 \\
94,754 \\
94,318 \\
90,401 \\
75,469 \\
51,154 \\
51,115\end{array}$ & $\begin{array}{c}2004 \\
2008 \\
\mathrm{x} \\
2009 \\
2007 \\
2005 \\
2008 \\
\mathrm{x} \\
\mathrm{x} \\
\mathrm{x}\end{array}$ & $2004-2010$ & $\begin{array}{r}32,015 \\
10,300 \\
0 \\
8,790 \\
15,500 \\
12,717 \\
7,600 \\
0 \\
0 \\
0\end{array}$ & $\begin{array}{c}0.19 \\
0.10 \\
\mathrm{x} \\
0.09 \\
0.16 \\
0.13 \\
0.08 \\
\mathrm{x} \\
\mathrm{x} \\
\mathrm{x}\end{array}$ \\
\hline
\end{tabular}

Tab. 4. Basic data on regional capitals and realised office construction over the past 20 years (Note: *rank-size rule according to Hampl, 2005)

Source: Czech Statistical Office (2011), Cushman \& Wakefield (2011), calculations of the authors 
Blažek (1996) and his finding that the headquarters of the major firms and firms from within the progressive tertiary sector, were significantly concentrated in Prague (or its metropolitan area) in the mid-1990s compared to the rest of the CR. These firms are perceived as an important source of potential demand for modern offices, and the concentration (and cooperation) tendencies in the progressive tertiary sector can be thought of as another demand-stimulating factor.

Office development in the Capital City is underlain not only by growing demand (the most important factor of the "property markets" aggregate) but by other factors as well. The potential generated by the emerging real estate market had attracted a number of foreign development companies and might have served as a basis for the creation of Czech developers (frequently, major Czech construction companies, such as Metrostav, expanded their business to include the development of office buildings), which might have resulted in the implementation of the first projects. The unique position of Prague in terms of its social structure - in our questionnaire survey, human and social capital was identified by the developers and other real estate professionals as the second most important aggregate affecting construction - played an important role in the Czech Republic as well. In this aggregate, the respondents laid emphasis on two relatively stable factors - population size and civic amenities. Thus, we believe that the development of the office market in Prague was further affected mainly by the population size of the Capital City (concentrating more than one tenth of the State's population) and an adequate offer of services. The dominant position of Prague in the Czech administrative market was also strongly supported by the high percentage of employees in the progressive tertiary sector ("Economy" aggregate $)^{1}$. This indicator reached $9.77 \%$ in the Capital City in 1996, which was more than double the second one - Brno (or the Jihomoravský Region) with $4.4 \%$.

Combined with (long-term) low registered unemployment and considerably higher average wages compared to other regions, it meant a substantial comparative advantage on the basis of which Prague had probably got a permanent jump on other capitals with respect to its economic position in the Czech Republic. Besides the comparative advantages referred to above, Prague also benefitted from being located centrally both in the State and Central Europe and, as far as transport is concerned, from the presence of an international airport and motorways to Moravian and Slovak metropolises, although motorway construction after 1990 lagged behind the growing demand for road infrastructure (Marada, 2006).

There was no construction in progress in other Czech regional capitals for several reasons. First of all, there was no local demand for modern offices and foreign companies concentrated exclusively on Prague in this period. The fact that other capitals were unprepared to absorb progressive tertiary sector companies certainly played a role, too: most out-of-Prague regions had to cope with the 'socialist heritage' - 'inconvenient' industry structure (e.g. the mining industry in basin areas - e.g. Ostrava, Ústí nad Labem, Karlovy Vary; the textile industry - Liberec; heavy machinery industry Brno, Plzeň, etc.), underdeveloped infrastructure (only Prague, Brno and Jihlava had access to the Czech motorway network in 1991), etc. Last but not least, the low proportion of employees in the progressive tertiary sector in out-of-Prague regions and growing unemployment outside Prague suggest that, economically, all out-of-Prague regions had lagged considerably behind Prague in this period (Blažek, 2001). This can be therefore perceived as 'lagging behind' in terms of office construction potential.

\section{B) 1997-2003 (administrative market development or growing construction intensity)}

In this phase, office construction in Prague becomes intensive and expands in Brno and Ostrava, i.e. the second category of towns we have defined.

On average, 88 thousand $\mathrm{m}^{2}$ of offices were annually built in Prague during this period, while in the first phase it was just 30 thousand $\mathrm{m}^{2}$. The significant increase in built administrative buildings and the further strengthening of Prague's position in the real estate market were predominantly backed by high demand for modern offices and the overall economic development of the Czech Republic stimulating the expansion of the private sector (ARTN, 2002). Sýkora (2007) clarifies this situation - while demand had been shaped by the entrance of firms to the Czech market until 1997, it was more strongly driven by the expansion of already-established Prague companies in the second half of the 1990s. As mentioned by Blažek (2001), Prague or the Prague metropolitan area maintained a dominant position at the beginning of the previous decade in terms of the concentration of the headquarters of major firms and progressive tertiary sector firms, compared to the rest of the Czech Republic.

One of the possible interpretations is that Prague continued to keep its dominant position from the point of view of a source of potential demand as opposed to other Czech towns and cities. This consideration is confirmed by Czech Statistical Office data showing another increase in the proportion of progressive tertiary sector employees in that period against the previous period. Apart from the growing demand, office construction growth was supported by the creation of an investment market (the "Property Markets" aggregate factor and generally one of the most highlyrated factors by the developers in our research) - the first let office building was sold to a foreign investor in Prague in 1998. While the first phase was characterized only by the establishment of developers in the real estate market in Prague, actual development was an element of the second phase. Concurrently, renowned real estate agencies that had established themselves in the Czech real estate market, started to educate the market. The education was based on presenting the advantages of newly-built offices which used integrated facility management services, were space-efficient and less energy-intensive, compared to old buildings or partially rehabilitated buildings (Trend Report, 2004).

The first modern office buildings in Brno and Ostrava were finished in 1997 and 2003, respectively. The construction of administrative buildings in both of these towns developed in connection with a trend of relocating some of the supportive business departments (such as call centres and back-up departments), the expansion of IT firms outside Prague (ARTN, 2002, 2004) and, above all, with an altered attitude of developers and real estate investors towards these areas. The most frequent motive for relocation was mainly high rent (see Tab. 4), increasing labour costs and the low unemployment rate in Prague, which encouraged a lot of

\footnotetext{
${ }^{1}$ Blažek and Csank (2007) reported, based on monitoring the unemployment rate development, GNP, entrepreneurial activity and revenues from tax on the income of natural persons, which inter-regional differences or differences between Prague and the remaining regions, ceased to deepen after 2000.
} 
foreign companies to choose these towns to cut costs and find employees for newly-created jobs more easily. Further, both of the towns offered a large number of students of information technologies and other fields convenient for firms requiring modern offices, and, last but not least, put extraordinary emphasis on science, research and university education development and image improvement.
On the other hand, developers sought substantially less expensive lands outside Prague (Sýkora, 2007), and by expanding to other towns and cities they aimed to eliminate growing competition in the form of newly-accomplished administrative projects, as well as the partial saturation of the market in the Capital City (ARTN, 2004; 2006) ${ }^{2}$. Looking more closely at data for selected indicators, one might

\begin{tabular}{|c|c|c|c|c|}
\hline 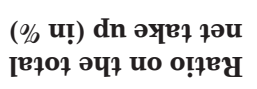 & 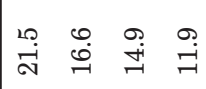 & 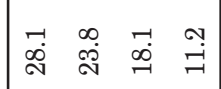 & 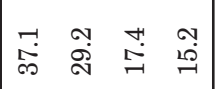 & \\
\hline 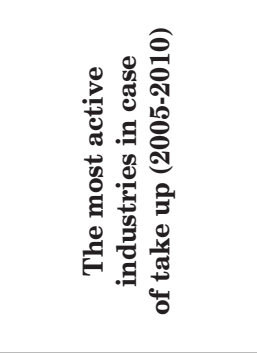 & 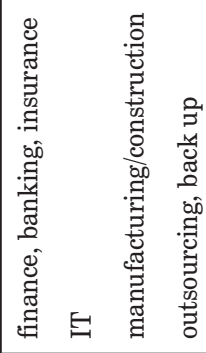 & 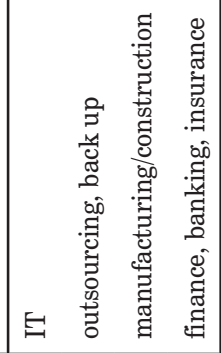 & 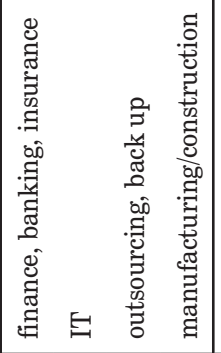 & $\star$ \\
\hline 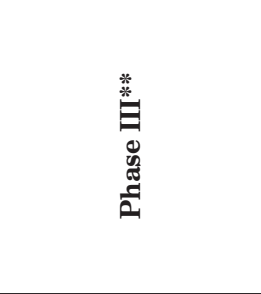 & 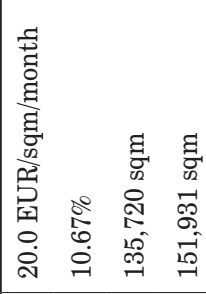 & 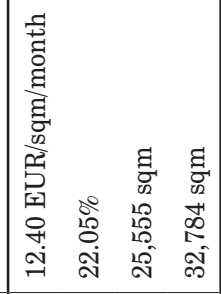 & 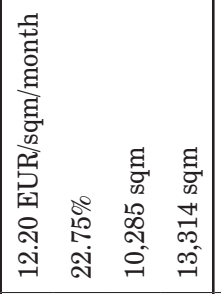 & 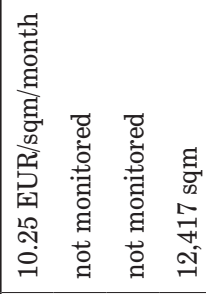 \\
\hline 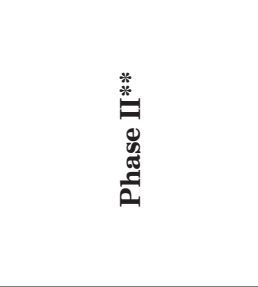 & 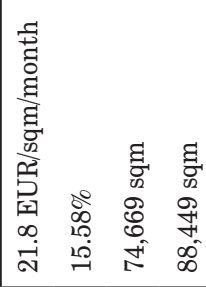 & 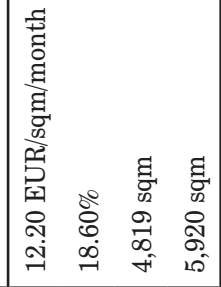 & 善 & $\rtimes$ \\
\hline 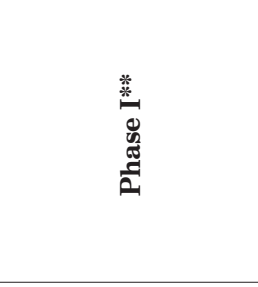 & 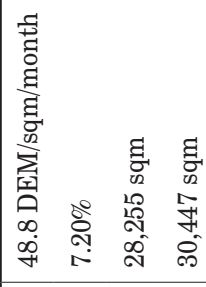 & $x$ & $\rtimes$ & $\rtimes$ \\
\hline 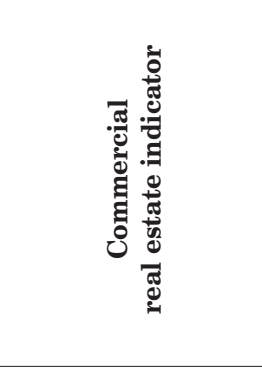 & 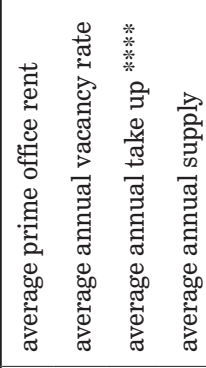 & 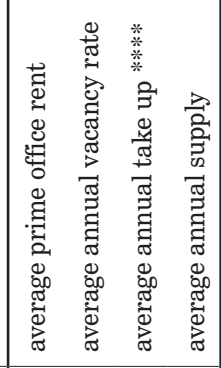 & 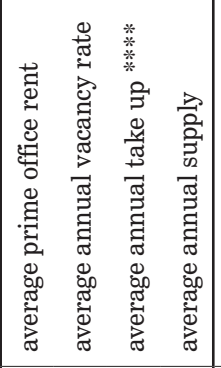 & 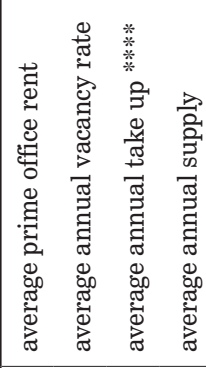 \\
\hline К! & 总 & 总 & 苞 & 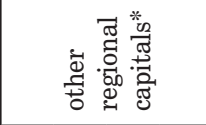 \\
\hline 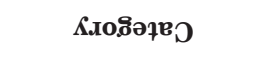 & - & $\exists$ & $=$ & 目 \\
\hline
\end{tabular}

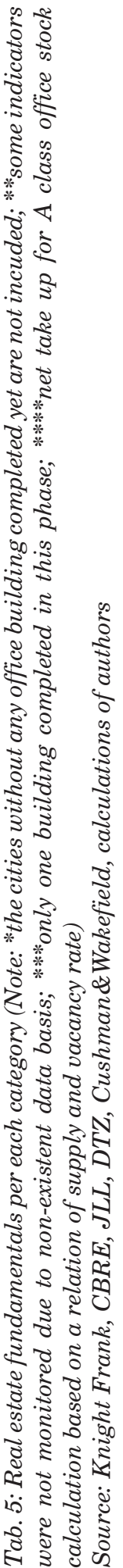

\footnotetext{
${ }^{2}$ In the second phase, the vacancy rate for offices in Prague was $15.58 \%$ annually on average, and supply exceeded demand for a long time (Table 5). According to the PRUPIM's methodology of vacancy rate calculation (www.prupim.com), vacancy rates higher than $6.7 \%$ in Europe are considered a competitive environment. Therefore, high vacancy rates in Prague at the beginning of previous decade can be perceived as highly competitive for office development.
} 
wonder why there was a six-year delay in the development of office construction in Ostrava compared to Brno. We believe that it was caused by the interplay of several factors. Unlike Brno, Ostrava was perceived quite negatively in the 1990s. Firstly, firms and developers were confronted, in the case of Ostrava, with the poor image of a structurally handicapped region without the presence of a larger number of services. Developers were discouraged from their activities also by the greater availability of lower-standard office areas previously used by former industrial businesses. The better accessibility to Prague, Bratislava or Vienna from Brno by road, played an important role, too, while Ostrava did not have any access to the motorway network or high-speed railway.

For other towns, this phase was notable in that it brought a reform of local governments and the formation of new Regions, as of 1 January, 2000. Olomouc, Liberec, Pardubice, Zlín, Karlovy Vary and Jihlava became new regional capitals, which enhanced their regional importance. This change had no impact on the construction of office buildings at first, however, because no modern administrative building was finished in these towns in this period. Nevertheless, some developers started to prepare construction projects for areas outside of Prague, Brno and Ostrava, owing to the favourable economic development of the Czech Republic and the related increasing demand of firms for offices in smaller towns (due to savings). The relocation of firms' supporting departments from Prague to these towns was motivated, in a similar fashion to that of Brno and Ostrava, by the minimization of costs and better availability of labour than in Prague, where there had been the lowest unemployment rate on a long-term basis and considerably higher wages. The developers' motivation to carry out projects in these towns was analogous to the cases of Brno and Ostrava, i.e. better availability of cheaper lands and an escape from the highly competitive environment in Prague. The gradual improvement of transport accessibility to the towns outside Prague is considered another impulse to increase their attractiveness in terms of future demand and development. In the period 2001-2004 railway corridors connecting Prague with Ústí nad Labem, Pardubice, Olomouc, Ostrava and Brno were reconstructed, and new motorways were built. Although motorway construction was far more intensive after 1998, no motorways were finished at that time.

\section{C) 2004-2010 (most intensive construction, its decrease and subsequent stagnation)}

In the last period we have defined, the market for administrative premises went through a phase of continuing development and then a rapid construction drop after 2009. Similar trends were recorded in other CEE capitals, such as Budapest or Warsaw. This period is characterised with office buildings being constructed in towns other than Prague, Brno and Ostrava - those we have assigned to the third size category - Plzeň, Hradec Králové, České Budějovice, Liberec, Pardubice and Ústí nad Labem. Only in Olomouc, Zlín, Karlovy Vary and Jihlava were there no international top-quality standard rental administrative units built.

Accession of the Czech Republic to the EU in 2004 appears to be an important milestone, as it strengthened the belief of institutional investors in the real estate market. After 2004 the average annual volume of investments in administrative buildings increased to almost 700 million EUR per year, compared to about 150 million EUR per year in the previous period. Almost all of the investment transactions, however, were in Prague. Contributing to the further reinforcement of the Capital City's dominant position in the administrative market, the increased capital inflow helped implement a larger number of development projects there. On average, about 151 thousand $\mathrm{m}^{2}$ of offices were annually built in Prague in the period 2004-2010, which is twice the amount in the previous period (see Tab. 4).

Of course, investment market activities were just one of the impulses intensifying construction in Prague. As in the previous phases, an essential role was played by demand for offices (ARTN, 2010), which was driven, analogously to the previous period, by the further expansion of companies, the need to raise user standards for offices, and the relocation of supporting departments of international firms to Prague. The increased activity of firms and the related need for more premises was driven especially by economic growth, foreign trade development, the further development of services and growing consumption by the population (ARTN, 2006; 2008; 2010). The trend of growing demand for offices in Prague is evidenced by another increase of the proportion of employees in the progressive tertiary sector, as opposed to most of the remaining regions. In this period, the development of other reporting indicators - the number of university students and average wages - confirms that Prague was well ahead of other regions in these categories, which we perceive as another comparative advantage of the Capital City for further office construction.

Construction in Brno in this period was motivated by the demands of IT firms (e.g. ICZ, IBM, Honeywell, Acer, Seznam), out-sourcing firms (e.g. Giga Byte), and financial institutions (e.g. Volksbank CZ) (ARTN, 2006; 2008; 2010). Brno's attractiveness was supported by the fact that it was an important European trade-fair centre, as well as an important base for research and development and technological centres, which influenced a number of companies in their location decisions (Fig 4, see cover p. 4). In Ostrava or the Moravian-Silesian Region (Ostrava's catchment area, with approximately 1 million inhabitants), demand for offices was driven by IT firms (TIETO), supporting bank departments (HSBC), large industrial holdings or companies providing support to these holdings. Demand for offices had been largely encouraged by the development of sub-contractor and advisor firms in the region, due to the opening of a Hyundai plant in Nošovice and a KIA plant in nearby Žilina. The town became even more alluring to firms and developers in 2006 when a regular link (with high-speed Pendolino trains) was opened up to Prague, and the town was connected to the Czech motorway network in 2010. New airport terminals were finished in both towns in 2006. The new terminal had almost doubled the capacity of the international airport in Brno-Turany; the new airport hall at Ostrava-Mošnov's Leoš Janáček Airport had the same impact on the airport's terminal capacity.

Construction development in the remaining regional capitals (i.e. the third category defined above) after 2004 in fact reacted to newly-emerging demands for supporting units and call centres outside Prague, Brno and Ostrava (ARTN, $2006,2008,2010$ ). The demand for such units mostly came from financial institutions (Raiffeisenbank in the Ústí nad Labem Region, ČSOB in Hradec Králové, Česká Spořitelna and $\mathrm{KBC}$ in Brno, etc.), and telephone operators (e.g. T-Mobile in Hradec Králové). Another important source of regional demand were the requirements of State institutions, especially bodies in charge of the European Union agenda (ARTN, 2008). Office construction in Plzeň developed in this 
phase mainly because a very large number of logistics and industrial parks had been built in the town's vicinity from the mid-1990s, which brought a need for offices by firms operating in the parks, as well as companies cooperating with the park tenants. Technological research and development traditions at the local university and the presence of IT fields of study played a role, too. Therefore, interest in the locality had been shown by a number of IT firms or companies with business links to Germany (ARTN, 2008).

Significantly less office areas were built in the other towns of the same category - Ústí nad Labem, Hradec Králové, Pardubice and Liberec (Tab. 4). This can be explained not only by low demand for the product but also by developers' mistrust of construction in areas lagging significantly behind in terms of social and human capital, and economic factors, despite the continuously improving transport accessibility of the towns and incomparably lower company operating costs than in Prague, including rent. Factors that had undoubtedly contributed to the increased attractiveness of these towns in this period may include a significant growth in the number of university students and improving transport accessibility. At the beginning of the period, railway corridors connecting Prague and Pardubice and Prague and Ústí nad Labem were finished (they were the first links to be served by Pendolino trains). The D11 Motorway was completed to the outskirts of Hradec Králové and Pardubice in 2006, which resulted in much better transport accessibility to both regional capitals. The R10 was finished a year later, together with the follow-up R35, and this improved Liberec's connection to the main road network. In comparison, Zlín has not seen Motorways R55 and follow-up R49 finalized yet, but the former one ends at Zlín's outskirts and has significantly reduced the travelling time from this town to other Czech towns.

Not a single building of concern for this study, however, was built in four regional capitals in this phase: Olomouc, Karlovy Vary, Zlín and Jihlava. In the case of Olomouc and Zlín, this is a surprising finding because both towns, or their regions show similar values for the reporting indicators as the other towns in this third size category, but where construction had started in this period. We believe that this is largely due to the closeness of these two towns to Ostrava and Brno (note: Olomouc and Zlín Regions used to be parts of the North Moravian and South Moravian Regions, respectively, until 2000, providing them with additional support), and related lagging behind Ostrava and Brno in all size and importance criteria. Thus, it is only logical for both companies demanding modern offices and developers to prefer Ostrava or Brno, which have historically made up significant ground in terms of business development conditions and factors affecting construction (especially social and human capital, and economy), compared to Olomouc and Zlín.

As far as Jihlava and Karlovy Vary are concerned, both towns meet some of the criteria for the construction of administrative buildings - they are connected to major roads, have low labour costs, and a general unemployment rate not much different from the other towns. Moreover, Karlovy Vary had the hall of its international airport modernized in 2006 and is a sought-after spa centre, as well as the scene of international cultural events. There might be several reasons why construction has not been launched in the four towns at this time. A low population size (about 50 thousand inhabitants) or the size of the catchment/work-commuting region, are seen to be essential limiting factors in Jihlava and Karlovy Vary. Neither of these towns has a university of its own, and there is a low number of university students in these regions compared to the other regions. The lowest unemployment rate in the progressive tertiary sector on a long-term basis has also contributed to the situation in Jihlava or Vysočina Region.

There has been a drop in the overall volume of office construction in all reporting size categories in the Czech Republic after 2008, due to the financial and economic crisis (see Fig. 3). The primary cause was not only universal factors, especially restrictions on the debt financing of construction by banks and the reduced inflow of capital from institutional investors to the Czech Republic or Prague, but also a drop in demand for modern offices, with considerable regional differences (ARTN, 2010).

\section{Discussion and conclusions}

Office construction is a dynamic process reflecting the qualitative importance of towns. Such quality has been partially explained, using several aggregates and an example of indicators representing selected factors. Yet it is obvious that there are other factors for the localization of construction of administrative buildings that have not been defined by the developers in our questionnaire survey. The volume of office construction has been increasing in Prague in the last twenty years proportionately to its increasing primary position as the Capital City. In other words, Prague has kept well ahead of other Czech towns in terms of the intensity and extent of this phenomenon. Certain differences among the rest of the towns have been reflected by the demand situation and the towns' socio-economic development. When comparing the total volumes of office construction, Prague's volume is approximately seven times higher than what has been built in Brno and more than twenty times higher than what has been built in Ostrava, in these twenty years.

Expressed in terms of office construction, differences in the quality of Czech towns partially coincide with the results of Hampl (2005), who represented the quality of towns with the aggregate "Qualitatively Adjusted Complex Size", calculated using the number of inhabitants and the number of job opportunities weighted by the proportion of quaternary activities. The largest difference between these two types of qualitative monitoring of Czech towns is, in particular, in the perception of Brno and Ostrava: considering the total office area, time of creation of the office market, and presence of the investment market, Brno is at a significantly higher level than Ostrava, whereas Hampl (2005) classifies these towns as similar (see below). These differences might be attributed to the insufficiently long period of development of construction of modern office buildings: we have analysed a developing process whereas Hampl analysed a "state" situation, which had been forming for a significantly longer period of time.

When explaining regional differentiation in the construction of administrative buildings, it is worth noting the 'horizontal' geographical location of the individual towns. Regional capitals in close proximity to more developed European countries ("European Core") are endowed with office space, but some of the Moravian towns showing similar values for the reporting characteristics, have not recorded the trend of construction of modern office buildings (e.g. Olomouc and Zlín). The absence of the trend could have been expected in regional capitals with low population and regional importance (Karlovy Vary, Jihlava). 
The questionnaire survey results revealed that the real estate market experts participating in the survey include the following factors among the most important for the localization of office construction: the situation in the real estate market (especially demand and investment markets), those indicators aggregated in the groups "Social and Human Capital" and those in "Economy". Respondents in general laid less emphasis on transport accessibility and the role of local activities, and least emphasis on environmental conditions Although the conclusions are determined by the number of indicators obtained from the controlled interviews and by excluding universal factors, the derived aggregation provides an alternative to the models of Fisher and Collins (1999) and Fisher (2005), moving them forward by additionally specifying the importance of individual factors or groups of factors (aggregates), although the assigned weights are only approximate and applicable only for this example of the Czech Republic. The role of these individual aggregates has been confirmed in the subsequent interpretation of data for the construction of office buildings.

In the Czech Republic, the first period was characterised by the creation of the real estate market in the reporting towns and the gradual trend of accepting the construction of modern office buildings. The development of the reporting indicators, substituents of individual factors evaluated within the questionnaire survey, was interesting, too. Prague has maintained its lead in all reporting indicators (population size, proportion employed in the progressive tertiary sector, registered unemployment rate, number of university students, and access to the transport network), in particular in the last ten years, with its leading position established approximately by 2002 .

Brno has profiled itself as a town with developing services, research and development from the beginning of the transformation, and the number of university students and progressive tertiary sector employees has significantly increased in the adjacent region in the last ten years. Moreover, the town has been perceived well in terms of its transport accessibility and international recognition (trade fairs). By contrast, Ostrava with a similar number of inhabitants, was associated by the developers with heavy industry and a poor environment. The negative image of the North Moravian city has been brought on also by other factors, such as a substantially lower number of university students than in Brno, worse transport accessibility until 2006, increased unemployment rate, an under-qualified labour force in the Region and a large amount of free lowerstandard offices in the town itself. This might provide an explanation why about 2.7 times more modern offices were built in Brno than in Ostrava in the reporting period.

Far less office buildings have been built in the remaining towns, broadly after 2004 , and they are lagging appreciably behind the three largest Czech towns in most of the reporting indicators. Due to the short time horizon over which the construction of administrative buildings has been monitored, while accompanied by a range of "unexpected" macroeconomic and political changes, and a certain immaturity or nonexistence of regional markets of administrative premises in some of the towns, we believe that the qualitative differentiation of Czech towns using this example of office construction, will require an analysis over a substantially longer time horizon. Even the state and development of several of the reporting indicators suggest that there is still potential for further construction of modern office buildings in the second and, in particular, third category of the towns.
It has been confirmed from the example of Prague (and Brno and Ostrava, to a much smaller extent) that progressive tertiary services are strongly concentrated in the most important towns (Blažek, 1996; Blažek, 2001). Our findings regarding office development suggest that while offices in Prague were generally researched by Czech companies' headquarters or national firms' branches (for more, see Blažek, 2001), usually lower-ranked departments within a corporate hierarchy (call centres, development centres, outsourcing services, etc.) were placed into other towns. This implies that we may observe patterns of the spatial distribution of work also using the example of the spreading construction of administrative buildings and its related structure of demand (see Massey, 1995; Blažek, 1996; Blažek, 2001).

Our objective was to study the construction of administrative buildings in the regional centres of the Czech Republic. We have explained some basic regional differences and their development over the last twenty years. Nonetheless, we are aware that the development of individual aggregates (and thus the overall construction volume in the country) was dependent particularly on the evolution of macroeconomic characteristics (e.g. the credit crunch in 2007-2009), and the political situation (e.g. the accession of the Czech Republic to the EU) at hierarchically higher levels. Therefore, further research on office construction in the Czech Republic should be carried out more broadly in the context of Central and Eastern Europe, and, most importantly, it should examine the interconnections between construction and the global economy, above all, the investment markets (e.g. Clark, Hebb and Wójcik, 2007; Engelen and Faulconbridge, 2009; Porteous, 1995).

\section{References}

AARHUS, K. (2000): Office location decisions, modal split and the environment: the ineffectiveness of Norwegian land use policy. Journal of Transport Geography, 8(4): 287-294.

ADAIR, A., BERRY, J., MCGREAL, S., SÝKORA, L., GHANBARI, P. A., REDDING, B. (1999): Globalisation of real estate markets in Central Europe. European Planning Studies, 7(3): 295-305.

ARTN (2002): Trend Report 2002 [online]. Prague: Association for Property Markets Development [cit. 14.10.2011]. Available at: http://artn.cz/cz/aktivity/trendreport/obecne-informace

ARTN (2004): Trend Report 2004 [online]. Prague: Association for Property Markets Development [cit. 14.10.2011]. Available at: http://artn.cz/cz/aktivity/trendreport/obecne-informace

ARTN (2006): Trend Report 2006 [online]. Prague: Association for Property Markets Development [cit. 14.10.2011]. Available at: http://artn.cz/cz/aktivity/trendreport/obecne-informace

ARTN (2008): Trend Report 2008 [online]. Prague: Association for Property Markets Development [cit. 14.10.2011]. Available at: http://artn.cz/cz/aktivity/trendreport/obecne-informace

ARTN (2010): Trend Report 2010 [online]. Prague: Association for Property Markets Development [cit. 14.10.2011]. Available at: http://artn.cz/cz/aktivity/trendreport/obecne-informace 
BERTZ, S. (2002): The peripheralisation of office development in the Dublin metropolitan area - the interrelationship between planning and development interests. Irish Geography, 35(2): 197-212.

BIČÍK, I., JANČÁK, V. (2006): Czech agriculture in the integrating Europe. Acta Geographica Universitatis Comenianae, 48(2): 155-165.

BIRELL, J., GAO, S. (1997): The property development process of phases and their degrees of importance. Cutting edge 1997, RICS.

BLAŽEK, J. (1996): Nové institucionální rámce ekonomiky a regionální rozvoj. In: Hampl, M et al.: Geografická organizace společnosti a transformační procesy v České republice (pp. 303-314). Univerzita Karlova v Praze, Př́rodovědecká fakulta, katedra sociální geografie a regionálního rozvoje, Prague.

BLAŽEK, J. (2001): Velké firmy a subjekty progresivního terciéru jako aktéři regionálního rozvoje v České republice. In: Hampl, M. et al.: Regionální vývoj: specifika české transformace, evropská integrace a obecná teorie (pp. 227-249). Univerzita Karlova v Praze, Př́rodovědecká fakulta, katedra sociální geografie a regionálního rozvoje, Prague.

BLAŽEK, J., CSANK, P. (2007): Nová fáze regionálního rozvoje v ČR? Sociologický časopis/Czech Sociological Review, 43(5): 945-965.

CARN, N., RABIANSKI, J., RACSTER, R., SELDIN, M. (1988): Real estate market analysis - Techniques and applications. Prentice Hall, Boston.

CLARK, G. L., HEBB, T., WÓJCIK, D. (2007) Institutional investors and the language of finance: the global metrics of market performance. In: Godfrey, J., Chalmers, K. [eds.]: Globalisation of Accounting Standards (pp. 15-33). Edward Elgar, Cheltenham.

CUSHMAN \& WAKEFIELD (2011): Internal database of office stock in the Czech Republic. Unpublished material.

CZSO (2011): Regional statistics, Czech Republic in Figures: Czech statistical office, 2011 [cit. 10.11.2011]. Available at: http://www.czso.cz/csu/2013edicniplan.nsf/engp/1410-13

D'ARCY, É., KEOGH, G. (1997): Towards a property market paradigm of urban change. Environment and Planning, 29(4): 685-706.

DES ROSIERS, F., THÉRIAULT, M. (2014): Retail Real Estate. In: Baker, H.K, Chinloy, P. [eds.]: Private Real Estate Markets and Investments: An Overview (pp. 87-106). Oxford University Press, New York.

DRBOHLAV, D., ČERMÁK, Z. (1998): International Migrants in Central European Cities. In: Enyedi, G. [ed.]: Social Change and Urban Restructuring in Central Europe (pp. 87-107). Akadémiai Kiadó, Budapest.

ENGELEN, E., FAULCONBRIDGE, J. (2009): Introduction: financial geographies-the credit crisis as an opportunity to catch economic geography's next boat? Journal of economic geography, 9(5): 587-595.

FISHER, P. (2005): The property development process: Case studies from Grainger Town. Property Management, 23(3): 158-175.

FISHER, P., COLLINS, T. (1999): The commercial property development process. Property Management, 17(3): 219-230.
GARB, Y., JACKSON, J. (2010): Brownfields in the Czech Republic 1989-2009: The Long Path to Integrated Land Management. Journal of Urban Regeneration and Renewal 3(3): 263-276.

GOTHAM, K. F. (2006): The secondary circuit of capital reconsidered: globalization and the US real estate sector. American Journal of Sociology, 112(1): 231-275.

HAMPL, M. (2010): Regionální diferenciace společnosti: obecné typy vývojových procesů. Geografie, 115(1): 1-20.

HAMPL, M. (2005): Geografická organizace společnosti v České republice: transformační procesy a jejich obecný kontext. Praha, Univerzita Karlova v Praze, Př́rodovědecká fakulta, Katedra sociální geografie a regionálního rozvoje.

HAMPL, M. et al. (2001): Regionální vývoj: specifika české transformace, evropská integrace a obecná teorie. Praha, Univerzita Karlova v Praze, Přírodovědecká fakulta.

HAVLÍČEK, T., CHROMÝ, P., JANČÁK, V., MARADA, M. (2005): Vybrané teoreticko-metodologické aspekty a trendy geografického výzkumu periferních oblastí. In: Novotná, M. [ed.]: Problémy periferních oblastí (pp. 6-24). Praha,Univerzita Karlova v Praze, Přírodovědecká fakulta, katedra sociální geografie a regionálního rozvoje.

ILÍK, J., OUŘEDNÍČEK, M. (2007): Karlín a jeho proměny v souvislostech postsocialistické transformace Prahy. Geografie-Sborník ČGS 112(3): 292-314.

LUX, M., SUNEGA, P. (2011): Labour Mobility and Housing: The Impact of Housing Tenure and Housing Affordability on Labour Migration in the Czech Republic. Urban Studies, 49(3): 489-504.

MARADA, M. (2006): Dopravní vztahy v Pražském městském regionu. In: Ouřednícek, M. [ed.]: Sociální geografie Pražského městského region (pp. 64-78). Praha, Univerzita Karlova v Praze, Př́rodovedecká fakulta, katedra sociální geografie a regionálního rozvoje.

MASSEY, D. (1995): Spatial Divisions of Labour: Social Structures and the Geography of Production. (2. ed.) London, Macmillan.

McGOUGH, A. J., TSOLACOS, S. (1997): The stylised facts of the UK commercial building cycles. Environment and Planning, 29(3): 485-500.

NEDOMOVÁ, E. [ed.] (1999): Trh bydlení, jeho regionální diferenciace a sociální souvislosti. Praha, Sociologický ústav AV ČR.

PARSA, A, McGREAL, S, KEIVANI, R. (2000): Globalisation of Real Estate Markets and Urban Development in Central Europe. RICS Cutting Edge Conference.

PORTEOUS, D. J. (1995): The geography of finance: spatial dimensions of intermediary behavior. Avebury, Aldershot.

PRAGUE RESEARCH FORUM (2014): Office Market Figures for Q2 2014 [cit. 15.8.2014]. Available at: http:// www.czech-office.cz/novinky/prague-research-forumannounces-the-office-market-figures-for-q2-2014/

PRUPIM (2011): Information about real estate investments [cit. 10.11.2011]. Available at: http://www.prupim.com

REBELO, E. (2010): Urban planning in office markets: A methodological approach. Land Use Policy, 28(1): 83-95.

SASSEN, S. (1995) On concentration and centrality in the global city. In: Knox, P. L., Taylor, P. J., [eds.]: World Cities In a World-system (pp. 63-78). Cambridge University Press. 
STANILOV, K. (2007): The restructuring of non-residential uses in the post-socialist metropolis. In: Stanilov, K. [ed.]: The Post-Socialist City: Urban Form and Space Transformations in Central and Eastern Europe after Socialism (pp. 73-99). Dordrecht, Springer.

SÝKORA, L. (2007): Office development and postcommunist city formation. In: Stanilov, K.: The PostSocialist City: Urban Form and Space Transformations in Central and Eastern Europe after Socialism (pp. 117145). Dordrecht, Springer.

SÝKORA, L., KAMENICKÝ, J., HAUPTMANN, P. (2000): Changes in the spatial structure of Prague and Brno in the 1990s. Acta Universitatis Carolinae Geographica 35(1): 61-76.
SÝKORA, L. (1999): Changes in the internal spatial structure of post-communist Prague. GeoJournal, 49(1): 79-89.

TEMELOVÁ, J. (2007): Flagship developments and the physical upgrading of post-socialist inner city: The Golden Angel project in Prague. Geografiska Annaler, 89B(2): 169-181.

VITURKA, M. (2010) Regionální disparity a jejich hodnocení v kontextu regionální politiky, Geografie, 115(2): 131-143.

WILKINSON, S., REED, R. (2008): Property development. (5. ed.) Abingdon, Routledge.

WOOD, A. (2004): The Scalar Transformation of the U.S. Commercial Property-Development Industry: A Cautionary Note on the Limits of Globalization Author(s). Economic Geography, 80(2): 119-140.

Initial submission 18 February 2014, final acceptance 20 November 2014

\section{Please cite this article as:}

DOMALEWSKI, P., BAXA, J. (2015): The development of regional differentiation of office construction in the Czech Republic: $1990-2010$. Moravian Geographical Reports, 23(1): 21-33. DOI: 10.1515/mgr-2015-0003. 